\title{
Plant protection costs in the selected farms in Lublin Voivodeship
}

\author{
Koszty ochrony roślin w wybranych gospodarstwach rolnych \\ województwa lubelskiego
}

\author{
Jolanta Bojarszczuk*, Janusz Podleśny
}

\begin{abstract}
Summary
The aim of the study was to evaluate the cost of plant protection in the selected farms in Lublin Voivodeship based on the results of a survey conducted in 2015. The study included the farms with an area of over 10 ha of agricultural land. For the analytical purposes the farms were divided into four groups (I-IV) differing in the area of agricultural land: 10-20, 20-30, 30-50, 50-100 ha. The expenditure on chemical plant protection varied and depended on the size of the farm and the species of crop. On the smallest farms, the amount of inputs measured in the quantity of active substance per hectare was about $44 \%$ lower than on the larger farms. The results showed that the application of herbicide was the highest, fungicides significantly smaller and insecticides the smallest. The highest amount of active substance per hectare was used in maize crops $(1.23 \mathrm{~kg})$, significantly less in winter wheat $(0.63 \mathrm{~kg})$ and the least in spring barley $(0.47 \mathrm{~kg})$. The profitability of plant protection treatments also varied in the each farms. In winter wheat cultivation it ranged from 5.4 to $6.8 \mathrm{dt}$ of grain and was the lowest in the farms from the area group of 20-30 ha. In the spring barley cultivation, it ranged from 6.28 to $8.90 \mathrm{dt}$ of grain were used to cover the cost of protective treatments. In maize cultivation, the value of this index varied between 34.6-45.7 dt and was the lowest on the smallest farms, and the highest on the farms from the area group of 20-30 ha. In the other two groups of farms the value of this index was similar and it amounted on average to $38.5 \mathrm{dt}$ of grain.
\end{abstract}

Key words: farm; cereal protection costs; profitability of production; Lublin Voivodeship

\section{Streszczenie}

Celem badań była ocena kosztów ochrony roślin w wybranych gospodarstwach województwa lubelskiego. Materiał źródłowy stanowiły wyniki badań ankietowych przeprowadzonych w 2015 roku. Uwzględniono typowo rolnicze gospodarstwa o powierzchni powyżej 10 ha użytków rolnych. Do celów analitycznych dokonano podziału gospodarstw na cztery grupy (I-IV) różniące się powierzchnią użytków rolnych: 10-20, 20-30, 30-50, 50-100 ha. Nakłady na chemiczną ochronę roślin były zróżnicowane i zależały od wielkości gospodarstwa i gatunku rośliny uprawnej. W gospodarstwach najmniejszych wielkość nakładów mierzona ilością substancji czynnej na ha była o około $44 \%$ mniejsza niż w gospodarstwach większych. W uprawie analizowanych gatunków roślin stwierdzono największe zużycie herbicydów, znacznie mniejsze fungicydów i najmniejsze insektycydów. Najwięcej substancji czynnej na 1 ha zużyto w uprawie kukurydzy $(1,23 \mathrm{~kg})$, znacznie mniej w uprawie pszenicy ozimej $(0,63 \mathrm{~kg})$ i najmniej w uprawie jęczmienia jarego $(0,47 \mathrm{~kg})$. Opłacalność zabiegów ochrony roślin była również zróżnicowana w poszczególnych gospodarstwach. W uprawie pszenicy ozimej wynosiła od 5,4 do 6,8 dt ziarna i była najniższa w gospodarstwach należących do grupy obszarowej 20-30 ha. W uprawie jęczmienia jarego na pokrycie kosztów zabiegów ochronnych przeznaczono od 6,28 do 8,90 dt ziarna. Natomiast w uprawie kukurydzy opłacalność była najniższa w gospodarstwach najmniejszych, a najwyższa w gospodarstwach należących do grupy obszarowej 20-30 ha. W pozostałych dwóch grupach obszarowych wartość tego wskaźnika była podobna i wynosiła średnio 38,5 dt ziarna.

Słowa kluczowe: gospodarstwo rolne; koszty ochrony zbóż; opłacalność uprawy; województwo lubelskie

\footnotetext{
Instytut Uprawy Nawożenia i Gleboznawstwa - Państwowy Instytut Badawczy w Puławach

Czartoryskich 8, 24-100 Puławy

*corresponding author: jbojarszczuk@iung.pulawy.pl
} 


\section{Wstęp / Introduction}

Zwiększenie chemicznej ochrony nastąpiło w Polsce w okresie po przystąpieniu do Unii Europejskiej (UE), co może wynikać ze wzrostu dochodów ze sprzedaży produktów rolnych oraz wprowadzeniu dopłat bezpośrednich (Falger i Jaworski 2011; Matyjaszczyk 2011). Zużycie środków ochrony roślin na 1 ha gruntów ornych i sadów w Polsce wzrosło w tym czasie o $17 \%$. Europa stała się największym odbiorcą środków ochrony roślin, stanowiącym ponad 29\% światowej sprzedaży (Pruszyński 2007). W latach 2004-2009 średnie zużycie środków ochrony roślin na 1 ha gruntów ornych i sadów wynosiło 1,46 kg substancji czynnej (s.cz.) (GUS 2011; Matyjaszczyk 2011; Zalewski 2014). Obecnie w Polsce ma miejsce powolny, ale stały i systematyczny wzrost zużycia chemicznych środków ochrony roślin. Jednocześnie szybko maleje sprzedaż środków ochronnych produkcji krajowej. Ponadto wzrasta sprzedaż środków importowanych (Urban 2016). Sprzedaż środków ochrony roślin w Polsce w 2012 roku była na poziomie 400 mln euro lub 13,3 tys. $t$ s.cz. W przeliczeniu na 1 ha użytków rolnych była wyraźnie niższa niż przeciętnie w UE (Matyjaszczyk 2014).

Z ekonomicznego punktu widzenia szczególne znaczenie ma efektywność ochrony roślin, w tym rachunek kosztów wykonywanych zabiegów.

Celem przeprowadzonych badań była ocena kosztów ochrony roślin w wybranych gospodarstwach województwa lubelskiego.

\section{Materiały i metody / Materials and methods}

Materiał źródłowy stanowiły wyniki badań ankietowych przeprowadzonych w 2015 roku w wybranych gospodarstwach, w województwie lubelskim. Dane niezbędne do przeprowadzenia analizy pochodzą z sezonu wegetacyjnego 2015 roku. W badaniach uwzględniono typowo rolnicze gospodarstwa o powierzchni powyżej 10 ha użytków rolnych. Do celów analitycznych dokonano podziału gospodarstw na cztery grupy (I-IV) różniące się powierzchnią użytków rolnych: 10-20, 20-30, 30-50, 50-100 ha. Wyboru gospodarstw dokonano w sposób celowy, przy współpracy z Lubelskim Ośrodkiem Doradztwa Rolniczego (LODR) w Końskowoli. Polegało to na świadomym wyborze obiektów $\mathrm{z}$ interesującej populacji na podstawie precyzyjnie określonych kryteriów zapewniających kontrolę zarówno homogeniczności, jak i zróżnicowania próby. Pomimo pewnych ograniczeń wynikających z braku możliwości uogólnienia próby, celowy dobór jest często stosowany w tego typu badaniach rolniczych, ponieważ pozwala na poznanie różnych zależności występujących w badanej zbiorowości (Kołoszko-Chomentowska 2013). Badane gospodarstwa charakteryzowały się znacznie większą powierzchnią użytków rolnych (tab. 1) w porównaniu do średniej $w$ województwie (7,65 ha) i kraju (10,56 ha) (GUS 2016). Ankiety zostały przygotowane w Zakładzie Uprawy Roślin Pastewnych Instytutu Uprawy Nawożenia i Gleboznawstwa - Państwowego Instytutu Badawczego w Puławach, natomiast dane nanieśli pracow- nicy LODR w Końskowoli. Każda ankieta zawierała pytania o: dane ogólne o gospodarstwie, strukturę zasiewów oraz szczegółowe dane dotyczące stosowanych technologii produkcji roślinnej, ze szczególnym uwzględnieniem ochrony roślin. Objęte analizą gospodarstwa położone były w różnych powiatach województwa lubelskiego (rys. 1).

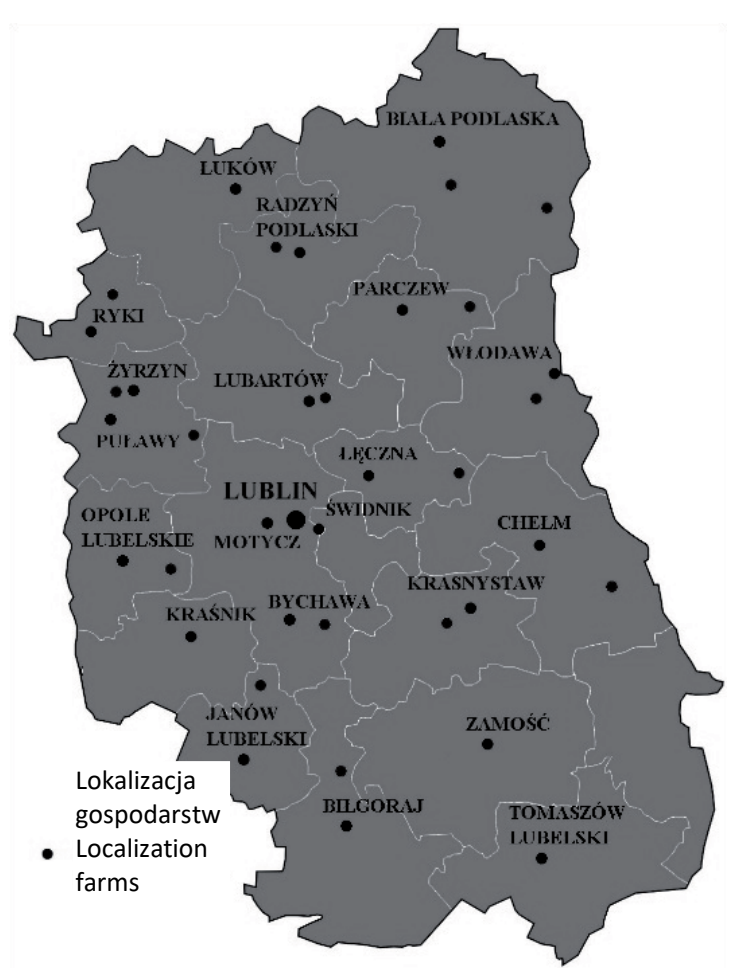

Rys. 1. Położenie badanych gospodarstw w województwie lubelskim

Fig. 1. Localization of researched farms in Lublin Voivodeship

Rachunek kosztów ochrony roślin przeprowadzono w oparciu o następujące wskaźniki: ilość zużytej substancji czynnej (s.cz. w kg/ha), liczbę zastosowanych zabiegów wykonanych pod poszczególne uprawy oraz faktycznie poniesione koszty zabiegów ochrony roślin (zł/ha) (Mierzejewska 1989; Golinowska 2002). Porównano koszty ochrony pszenicy ozimej, jęczmienia jarego i kukurydzy, w zależności od wielkości gospodarstwa, wyrażonej w powierzchni użytków rolnych. Określono również opłacalność zabiegów ochrony roślin za pomocą wskaźnika opłacalności ( $E_{1}$ i $\left.E_{2}\right)$. Opłacalność zabiegów obliczono za pomocą orientacyjnego wskaźnika opłacalności $\mathrm{E}_{1}$, który określa liczbę produktu chronionego pokrywającą koszty zabiegów ochrony roślin i $E_{2}$ mówiącego, jaki odsetek plonu należy przeznaczyć na zabiegi ochronne.

$$
\begin{aligned}
& \mathrm{E}_{1}=\mathrm{Kz} / \mathrm{C} \\
& \mathrm{E}_{2}=\mathrm{E}_{1} \times 100 / \mathrm{P} \\
& \mathrm{Kz}-\text { koszty zabiegów ochrony roślin }(\mathrm{z} \mathrm{h} / \mathrm{ha}), \\
& \mathrm{C}-\text { cena } 1 \mathrm{dt} \text { produktu chronionego }(\mathrm{zt} / \mathrm{dt}), \\
& \mathrm{P}-\text { plon produktu chronionego }(\mathrm{dt} / \mathrm{ha}) .
\end{aligned}
$$

Oceniono intensywność organizacji produkcji roślinnej, stanowiącą pochodną struktury użytkowania ziemi, którą obliczono metodą wskaźnikową według Kopcia (1987), przyjmując jednolite współczynniki przeliczeniowe. 
Tabela 1. Wybrane cechy analizowanych gospodarstw

Table 1. Selected characteristics of analyzed farms

\begin{tabular}{|c|c|c|c|c|c|}
\hline \multirow[t]{2}{*}{ Wyszczególnienie - Specification } & \multicolumn{4}{|c|}{$\begin{array}{l}\text { Grupa obszarowa gospodarstw } \\
\text { Area group of farms }\end{array}$} & \multirow{2}{*}{$\begin{array}{c}\text { Średnia } \\
\text { Mean }\end{array}$} \\
\hline & I & II & III & IV & \\
\hline Powierzchnia użytków rolnych - Land area in ha [ha] & 17,0 & 26,5 & 42,0 & 82,2 & 41,9 \\
\hline \multicolumn{6}{|c|}{ Plon wybranych gatunków roślin - Yield of selected plants [t/ha] } \\
\hline Pszenica ozima - Winter wheat & 5,5 & 5,8 & 5,0 & 5,8 & 5,5 \\
\hline Jęczmień jary - Spring barley & 5,0 & 4,8 & 4,9 & 5,1 & 5,0 \\
\hline Kukurydza (na kiszonkę) - Maize (for silage) & 52,5 & 44,0 & 51,0 & 58,3 & 51,5 \\
\hline \multicolumn{6}{|c|}{ Udział w strukturze zasiewów - Share in cropping system [\%] } \\
\hline Zboża-Cereals & 64,9 & 62,1 & 64,4 & 69,2 & 65,2 \\
\hline Kukurydza (na kiszonkę) - Maize (for silage) & 23,7 & 8,6 & 16,7 & 19,6 & 17,2 \\
\hline Inne - Others & 11,4 & 29,3 & 18,7 & 11,2 & 17,7 \\
\hline $\begin{array}{l}\text { Intensywność organizacji produkcji roślinnej [pkt] } \\
\text { Intensivity of organization of plant production [points] }\end{array}$ & 116 & 165 & 139 & 144 & 141 \\
\hline
\end{tabular}

Źródło: opracowanie własne

Source: own elaboration

\section{Wyniki i dyskusja / Results and discussion}

Objęte analizą gospodarstwa prowadziły działalność rolniczą na powierzchni 692,4 ha, w tym grunty orne zajmowały 582,2 ha, czyli stanowiły $84,1 \%$ UR. W gospodarstwach dominowały gleby należące do następujących kompleksów przydatności rolniczej: pszenny bardzo dobry, pszenny dobry, pszenny wadliwy i żytni bardzo dobry, które stanowiły 53,4\% gruntów ornych, natomiast gleby najlepsze (kompleks pszenny bardzo dobry i pszenny dobry) oraz najsłabsze (kompleks żytni najsłabszy) stanowiły odpowiednio 7,4 i 12,8\% ogółu gleb. Przeciętna wielkość gospodarstwa wynosiła 43,4 ha. Większość stanowiły grunty własne (około $80 \%$ ). Dzierżawienie gruntów występowało przede wszystkim $\mathrm{w}$ gospodarstwach największych. Na 1 zatrudnionego w gospodarstwie przypadało 19,2 ha, przy czym w gospodarstwach mniejszych - do 20 ha wskaźnik ten wynosił 14,2 ha, a w gospodarstwach powyżej 20 ha $-24,4$ ha.

W strukturze zasiewów badanych gospodarstw duży udział stanowiły zboża, osiągając najwyższy wskaźnik w gospodarstwach największych obszarowo $(69,2 \%)$. Plony uprawianych gatunków roślin były zróżnicowane w poszczególnych grupach gospodarstw. Średni uzyskany w badanych gospodarstwach plon pszenicy ozimej wynosił 5,5 t/ha, jęczmienia jarego - 5,0 t/ha, a kukurydzy $51,5 \mathrm{t} / \mathrm{ha}$. Najwyższe plony wszystkich uprawianych gatunków roślin uzyskano w gospodarstwach grupy IV. Poziom intensywności produkcji roślinnej w tych gospodarstwach był średni i ksztaltował się w granicach 116-165 punktów. Najwyższy poziom intensywności produkcji roślinnej zanotowano w II grupie gospodarstw (165 punktów).

Oddziaływanie struktury zasiewów na kształtowanie się zużycia środków ochrony roślin ma nie tylko znaczenie ilościowe. Ma również wpływ na indeks toksyczności środków ochrony roślin wynikający $\mathrm{z}$ rodzaju użytych s.cz., a tym samym na środowisko (Bieńkowski i wsp. 2005). Spośród grup roślin wzrost zużycia środków ochrony roślin zależał głównie od zwiększenia udziału kukurydzy na ziarno $\mathrm{w}$ strukturze zasiewów. Zdaniem Jankowiaka i wsp. (2012) poziom stosowania chemicznej ochrony roślin (technologia i ilość środków ochrony roślin) związany jest $\mathrm{z}$ wielkością gospodarstwa.

Nakłady na chemiczną ochronę roślin w badanych gospodarstwach były zróżnicowane, o czym świadczą: zużycie środków ochrony roślin (s.cz.) w uprawie poszczególnych gatunków, liczba zabiegów oraz poniesione koszty (tab. 2). W gospodarstwach o powierzchni ponad 20 ha zużycie s.cz. na 1 ha UR było o około $77 \%$ większe niż w gospodarstwach najmniejszych (do $10 \mathrm{ha}$ ). W gospodarstwach najmniejszych (do 10 ha) wielkość nakładów mierzona ilością substancji czynnej na 1 ha była o około $44 \%$ mniejsza niż w pozostałych gospodarstwach.

Największym zużyciem środków ochrony roślin charakteryzowała się uprawa kukurydzy, zwłaszcza w gospodarstwach większych obszarowo (1,26-1,66 kg s.cz./ha), nieco mniejszym - uprawa pszenicy ozimej, a najmniejszym - jęczmienia jarego. Średnio dla wszystkich gospodarstw zużycie środków ochrony roślin $w$ uprawie pszenicy, kukurydzy i jęczmienia jarego wynosiło odpowiednio: 0,$63 ; 1,24$ i $0,47 \mathrm{~kg} / \mathrm{ha}$. Oznacza to, że w analizowanych gospodarstwach zużycie s.cz. na 1 ha było znacznie mniejsze niż średnio w Polsce. Według danych GUS (2016) w latach 2010-2013 wskaźnik zużycia środków ochrony roślin w s.cz. na 1 ha uprawy pszenicy ozimej wynosił bowiem 1,5 kg, kukurydzy - 1,2 kg i jęczmienia jarego $-0,6 \mathrm{~kg}$.

Najwyższe łączne koszty na ochronę roślin ponoszono w uprawie kukurydzy (średnio $497 \mathrm{zł} / \mathrm{ha}$ ) i jęczmienia jarego $(473 \mathrm{zł} / \mathrm{ha})$, natomiast znacznie niższe $\mathrm{w}$ uprawie pszenicy ozimej (386 zł/ha). Badania Hołaja (2011) wykazały, że najwyższe łączne koszty zastosowanej ochrony roślin generowała pszenica ozima, w uprawie której zastosowano cztery zabiegi, niższe o $35 \%$ jęczmienia jarego (trzy zabiegi ochronne), a dwukrotnie niższe owsa, w uprawie którego zastosowano dwa zabiegi. 
Tabela 2. Nakłady na chemiczną ochronę roślin w analizowanych gospodarstwach

Table 2. Expenditures on chemical plant protection in analyzed farms

\begin{tabular}{|c|c|c|c|c|c|}
\hline \multirow[t]{2}{*}{ Wyszczególnienie - Specification } & \multicolumn{4}{|c|}{$\begin{array}{l}\text { Grupa obszarowa gospodarstw } \\
\text { Area group of farms }\end{array}$} & \multirow{2}{*}{$\begin{array}{c}\text { Średnia } \\
\text { Mean }\end{array}$} \\
\hline & I & II & III & IV & \\
\hline $\begin{array}{l}\text { Zużycie ś.o.r. w kg s.cz./ha, w tym } \\
\text { Plant protection products utilization in kg of a.s./ha, including }\end{array}$ & 1,48 & 2,72 & 2,41 & 2,72 & 2,33 \\
\hline Pszenica ozima - Winter wheat & 0,68 & 0,75 & 0,5 & 0,58 & 0,63 \\
\hline Jęczmień jary - Spring barley & 0,33 & 0,42 & 0,65 & 0,48 & 0,47 \\
\hline Kukurydza - Maize & 0,47 & 1,55 & 1,26 & 1,66 & 1,24 \\
\hline Pszenica ozima - Winter wheat & 1 & 2 & 1 & 2 & 2 \\
\hline Jęczmień jary - Spring barley & 1 & 1 & 1 & 1 & 1 \\
\hline Kukurydza - Maize & 3 & 4 & 2 & 3 & 3 \\
\hline Zużycie ś.o.r. w zł/ha - Use of plant protection products in PLN/ha & 750 & 953 & 946 & 764 & 853 \\
\hline Pszenica ozima - Winter wheat & 192 & 279 & 276 & 185 & 233 \\
\hline Jęczmień jary - Spring barley & 208 & 272 & 281 & 170 & 233 \\
\hline Kukurydza - Maize & 350 & 402 & 389 & 409 & 387 \\
\hline Koszt zużycia ś.o.r. w zł/ha - Cost of using of plant protection products in PLN/ha & 1187 & 1564 & 1383 & 1289 & 1356 \\
\hline Pszenica ozima - Winter wheat & 367 & 454 & 364 & 360 & 386 \\
\hline Jęczmień jary - Spring barley & 383 & 534 & 543 & 432 & 473 \\
\hline Kukurydza - Maize & 437 & 577 & 476 & 497 & 497 \\
\hline Krotność zabiegów chemicznych - Number of chemical treatments & 5 & 7 & 4 & 6 & 6 \\
\hline
\end{tabular}

Źródło: opracowanie własne

Source: own elaboration

Największe nakłady na zużycie środków ochrony roślin, wyrażone zarówno kosztami zakupu środków ochrony, jak i ich zastosowania ponoszono w gospodarstwach w grupie II i III (odpowiednio: 953 i 946 zł/ha), a najmniejsze w gospodarstwach w grupie I ( $750 \mathrm{z} / \mathrm{ha})$. Wynika to z faktu, że w gospodarstwach najmniejszych stosowano mniej intensywną ochronę chemiczną, a w gospodarstwach największych kupowano tańsze środki chemiczne. W gospodarstwach najmniejszych (do 10 ha) wielkość nakładów mierzona ilością s.cz. na 1 ha była o około 44\% mniejsza niż w pozostałych gospodarstwach. W gospodarstwach z grupy I i IV nakłady na zużycie środków ochrony roślin w uprawie pszenicy ozimej i jęczmienia jarego były o około $30 \%$ niższe niż w II i III grupie gospodarstw.

Zużycie środków ochrony roślin w procesie produkcji było zróżnicowane. W strukturze zużycia środków ochrony roślin dominowały herbicydy i fungicydy, w gospodarstwach w grupie III również insektycydy (tab. 3). Największe zużycie herbicydów zanotowano w uprawie kukurydzy, zaś fungicydów w uprawie pszenicy (w grupie I i II) oraz jęczmienia (w grupie II i III). Stosowanie herbicydów i fungicydów w produkcji roślinnej jest w Polsce bardziej powszechne niż insektycydów, co potwierdzają także badania przeprowadzone w gospodarstwach wielkoobszarowych (Golinowska 2009) oraz w gospodarstwach indywidualnych (Golinowska i wsp. 2014).

Uzyskiwany plon i ceny sprzedaży mają istotny wpływ na kształtowanie się orientacyjnych wskaźników opłacalności. Dla producentów istotnie ważna jest skala kosztów, jakie będą poniesione przy ochronie upraw (Hołaj 2011). Określona na podstawie wybranych wskaźników opłacal- ność zabiegów ochrony roślin była również zróżnicowana dla poszczególnych gatunków uprawianych roślin oraz w poszczególnych grupach gospodarstw (tab. 4). W uprawie pszenicy ozimej na pokrycie kosztów chemicznej ochrony przeznaczono od 5,4 w gospodarstwach grupy III do 6,8 dt ziarna w gospodarstwach grupy II, co stanowiło odpowiednio: 10,9 i 11,7\% plonu. W badaniach Golinowskiej i wsp. (2014) przeprowadzonych w gospodarstwie indywidualnym położonym w województwie opolskim wykazano, że na pokrycie kosztów ochrony pszenicy ozimej należało przeznaczyć $15,1 \%$ plonu. Na kształtowanie się tego wskaźnika wpływ miało szereg czynników, takich jak: zastosowany środek i jego cena, wielokrotność zabiegu, cena produktu chronionego i uzyskany plon.

W przeprowadzonych badaniach na pokrycie kosztów zabiegów ochronnych w uprawie jęczmienia jarego należało przeznaczać od 6,28 w grupie I do 8,90 dt ziarna w grupie III, co stanowiło odpowiednio dla grup gospodarstw: 12,6 i 18,2\% uzyskanego plonu. Natomiast w uprawie kukurydzy wartość tego wskaźnika wahała się w granicach $34,6-45,7$ dt i była najniższa w gospodarstwach najmniejszych, a najwyższa w gospodarstwach należących do grupy obszarowej 20-30 ha. W pozostałych dwóch grupach obszarowych wartość tego wskaźnika była podobna i wynosiła odpowiednio: 37,7 i 39,3 dt. Również w badaniach Golinowskiej i wsp. (2013) wykazano, że koszty ochrony pszenicy ozimej są niższe niż rzepaku i buraka cukrowego, bowiem na pokrycie kosztów jej ochrony należało przeznaczyć 3,6 dt ziarna, co stanowi niespełna $7 \%$ plonu. 
Tabela 3. Ilościowa struktura zużycia środków ochrony roślin [\%]

Table 3. The quantity structure of utilization of plant protection products [\%]

\begin{tabular}{|c|c|c|c|c|c|}
\hline \multirow{2}{*}{$\begin{array}{l}\text { Wyszczególnienie } \\
\text { Specification }\end{array}$} & \multicolumn{4}{|c|}{$\begin{array}{c}\text { Grupa obszarowa gospodarstw } \\
\text { Area group farms }\end{array}$} & \multirow{2}{*}{$\begin{array}{c}\text { Średnia } \\
\text { Mean }\end{array}$} \\
\hline & I & II & III & IV & \\
\hline \multicolumn{6}{|c|}{ Herbicydy - Herbicides } \\
\hline Pszenica ozima - Winter wheat & 62,0 & 44,0 & 46,8 & 62,2 & 53,8 \\
\hline Jęczmień jary - Spring barley & 71,2 & 46,8 & 42,9 & 74,7 & 58,9 \\
\hline Kukurydza - Maize & 86,4 & 70,7 & 66,5 & 79,0 & 75,7 \\
\hline \multicolumn{6}{|c|}{ Fungicydy - Fungicides } \\
\hline Pszenica ozima - Winter wheat & 38,0 & 56,0 & 26,4 & 37,9 & 39,6 \\
\hline Jęczmień jary - Spring barley & 28,8 & 53,2 & 41,4 & 25,3 & 37,2 \\
\hline Kukurydza - Maize & 13,6 & 29,3 & 22,1 & 21,0 & 21,5 \\
\hline \multicolumn{6}{|c|}{ Insektycydy - Insecticides } \\
\hline Pszenica ozima - Winter wheat & 0 & 0 & 26,8 & 0 & 6,7 \\
\hline Jęczmień jary - Spring barley & 0 & 0 & 15,7 & 0 & 3,9 \\
\hline Kukurydza - Maize & 0 & 0 & 11,3 & 0 & 2,8 \\
\hline
\end{tabular}

Źródło: opracowanie własne

Source: own elaboration

Tabela 4. Wskaźnik opłacalności zabiegów ochronnych

Table 4. Index of profitability of protective treatments

\begin{tabular}{|c|c|c|c|c|c|}
\hline \multirow[t]{2}{*}{ Wyszczególnienie - Specification } & \multicolumn{4}{|c|}{$\begin{array}{l}\text { Grupa obszarowa gospodarstw } \\
\text { Area group farms }\end{array}$} & \multirow{3}{*}{$\begin{array}{c}\text { Średnia } \\
\text { Mean }\end{array}$} \\
\hline & I & II & III & IV & \\
\hline \multicolumn{5}{|c|}{$\begin{array}{l}\text { Wskaźnik opłacalności zabiegów }\left(\mathrm{E}_{1}\right)[\mathrm{dt}] \\
\text { Index of treatment profitability }\left(\mathrm{E}_{1}\right)[\mathrm{dt}]\end{array}$} & \\
\hline Pszenica ozima - Winter wheat & 5,49 & 6,79 & 5,44 & 5,39 & 5,78 \\
\hline Jęczmień jary - Spring barley & 6,28 & 8,75 & 8,90 & 7,07 & 7,75 \\
\hline Kukurydza - Maize & 34,6 & 45,7 & 37,7 & 39,3 & 39,3 \\
\hline \multicolumn{5}{|c|}{$\begin{array}{l}\text { \% zbioru na pokrycie kosztów ochrony }\left(\mathrm{E}_{2}\right) \\
\text { Share of harvest to cover of costs of plant protection }\left(\mathrm{E}_{2}\right)\end{array}$} & \\
\hline Pszenica ozima - Winter wheat & 9,9 & 11,7 & 10,9 & 9,2 & 10,4 \\
\hline Jęczmień jary - Spring barley & 12,6 & 18,2 & 18,2 & 13,9 & 15,7 \\
\hline Kukurydza - Maize & 6,6 & 10,4 & 7,39 & 6,7 & 7,77 \\
\hline
\end{tabular}

Źródło: opracowanie własne

Source: own elaboration

\section{Wnioski / Conclusions}

1. Nakłady na chemiczną ochronę roślin były zróżnicowane i zależały od wielkości gospodarstwa i gatunku rośliny uprawnej.

2. W uprawie analizowanych gatunków roślin stwierdzono największe zużycie herbicydów, znacznie mniejsze fungicydów i najmniejsze insektycydów. Najwięcej s.cz. na 1 ha zużyto w uprawie kukurydzy $(1,23 \mathrm{~kg})$, znacznie mniej w uprawie pszenicy ozimej $(0,63 \mathrm{~kg})$ i najmniej w uprawie jęczmienia jarego $(0,47 \mathrm{~kg})$.

3. Opłacalność zabiegów ochrony była zróżnicowana w poszczególnych gospodarstwach i wynosiła: w uprawie pszenicy ozimej od 5,4 do 6,8 dt, jęczmienia jarego od 6,3 do 8,9 dt i kukurydzy od 34,6 do 45,7 dt ziarna.
4. Najwięcej plonu na pokrycie kosztów zabiegów ochrony przeznaczano w uprawie jęczmienia jarego, znacznie mniej w uprawie pszenicy ozimej i najmniej w uprawie kukurydzy.

Praca wykonana w ramach realizacji zadania 2.3 Programu Wieloletniego Instytutu Uprawy Nawożenia i Gleboznawstwa - Państwowego Instytutu Badawczego w Puławach pt. „Wspieranie działań w zakresie ochrony i racjonalnego wykorzystania rolniczej przestrzeni produkcyjnej w Polsce oraz kształtowania jakości surowców roślinnych na lata 2016-2020”. 


\section{Literatura / References}

Bieńkowski J., Jankowiak J., Hołodyńska I. 2005. Zastosowanie wielokryterialnego indeksu oceny oddziaływania pestycydów na środowisko w różnych typach gospodarstw rolniczych. [Application of multi-criterial toxicity index for the assessment of pesticide impact on the environment in different farming types of farms]. Progress in Plant Protection/Postępy w Ochronie Roślin 45 (1): 52-59.

Falger P., Jaworski R. 2011. Udział kosztów chemicznej ochrony roślin w wybranych uprawach polowych w latach 2003-2009. [Share of the costs of chemical plant protection in selected field crops in 2003-2009]. Progress in Plant Protection/Postępy w Ochronie Roślin 51 (4): 1455-1463.

Golinowska M. 2002. Efektywność ochrony roślin w indywidualnych gospodarstwach rolnych południowo-zachodniej Polski. Zeszyty Naukowe Akademii Rolniczej we Wrocławiu 433, 199 ss.

Golinowska M. 2009. Nakłady na chemiczną ochronę roślin w gospodarstwach wielkoobszarowych na początku XXI wieku. Journal of Agriculture and Rural Development 2 (12): 53-60.

Golinowska M., Wiciak T., Kruszyński M., Adamska H. 2014. Intensywność nakładów na chemiczną ochronę roślin w gospodarstwie indywidualnym. [Intensity of expenditure on chemical weed control in an individual farm]. Roczniki Naukowe Stowarzyszenia Ekonomistów Rolnictwa i Agrobiznesu 16 (1): 50-56.

GUS 2011. Ochrona środowiska. Główny Urząd Statystyczny, Warszawa, 574 ss.

GUS 2016. Rocznik statystyczny rolnictwa. Główny Urząd Statystyczny, Warszawa, 452 ss.

Hołaj J. 2011. Straty plonu a próg opłacalności ochrony zbóż. [Crop losses and profitability threshold for cereals protection]. Inżynieria Rolnicza 1 (126): 77-83.

Jankowiak J., Bieńkowski J., Holka M., Dąbrowicz R. 2012. Zużycie środków ochrony roślin na tle zmian w produkcji rolniczej. [The consumption of plant protection products in the background of changes in agricultural production]. Progress in Plant Protection/Postępy w Ochronie Roślin 52 (4): 1177-1183.

Kołoszko-Chomentowska Z. 2013. Przyrodnicze i organizacyjno-ekonomiczne uwarunkowania rozwoju rodzinnych gospodarstw rolnych w województwie podlaskim. Monografie i Rozprawy Naukowe 41, 135 ss.

Kopeć B. 1987. Intensywność organizacji w rolnictwie polskim w latach 1960-1980. Roczniki Nauk Rolniczych, Seria G 84 (1): 8-25.

Matyjaszczyk E. 2011. Analiza zmian ustawodawstwa z zakresu ochrony roślin pod kątem bezpieczeństwa żywności, ludzi i środowiska. Rozprawy Naukowe Instytutu Ochrony Roślin - Państwowego Instytutu Badawczego 25, 130 ss.

Matyjaszczyk E. 2014. Rynek środków ochrony roślin w Polsce w 2012 roku w ujęciu ilościowym i wartościowym. Roczniki Naukowe Stowarzyszenia Ekonomistów Rolnictwa i Agrobiznesu 16 (3): 177-182.

Mierzejewska W. 1989. Rachunek kosztów w ochronie roślin. Zeszyty Problemowe Postępów Nauk Rolniczych 363: 9-21.

Pruszyński S. 2007. Ochrona roślin w Polsce i nowych krajach członkowskich Unii Europejskiej. Ochrona Roślin 2: 3-5.

Urban S. 2016. Zmiany w zużyciu środków ochrony roślin w Polsce i ich aspekty ekonomiczne. Roczniki Naukowe Stowarzyszenia Ekonomistów Rolnictwa i Agrobiznesu 16 (6): 505-509.

Zalewski A. (red.) 2014. Rynek środków produkcji dla rolnictwa. Analizy Rynkowe. Instytut Ekonomiki Rolnictwa i Gospodarki Żywnościowej - Państwowy Instytut Badawczy, Warszawa, 45 ss. 